\title{
The evolution of large mammal communities: beyond biochronology
}

\author{
Pasquale Raia ${ }^{1} \&$ Lorenzo Rook ${ }^{2, *}$
}

\author{
1) Dipartimento di Scienze della Terra, Ambiente e Risorse, Università di Napoli Federico II, \\ IT-80138 Napoli, Italy \\ 2) Dipartimento di Scienze della Terra, Università degli Studi di Firenze, via G. La Pira, 4, IT-50121 \\ Firenze, Italy ("coresponding author's e-mail: lorenzo.rook@unifi.it)
}

Received 24 June 2013, final version received 30 Sep. 2013, accepted 1 Oct. 2013

Raia, P. \& Rook, L. 2014: The evolution of large mammal communities: beyond biochronology. Ann. Zool. Fennici 51: 57-65.

Evolution is commonly studied at different levels, from genes to species. It has been questioned whether all these levels are actually real, although it now seems accepted by most scientific investigators that more than one level is actually targeted by selection. Intriguingly, despite the importance of biological interaction is relevant to the course of evolution (and to the level to which selection applies) the obvious locus for biological interaction, the community, has received little evolutionary attention by mammal paleontologists. Herein, we investigate the concept of a biochron, which is the approximation closest to a real community in the paleontological world, and its applications. Then, we offer some clues as to how to use biochrons for investigating community evolution, and explain why paleontological community evolution is a partly novel, highly promising field of research within the realm of paleobiology.

\section{Introduction}

Charles Lyell is known for his clear definition of the Eocene, Miocene and Pliocene epochs by counting the number of molluscan genera they contain which survive to the Recent. Biochronologic units thus were concerned with extinction dynamics from the very beginning. This implicitly evolutionary aspect of biochrons, an essential side that Lyell himself obviously had clear in his mind (Rudwick 1978), has been underestimated and partly unused since his time. However, another and possibly more explicit value of biochronologic intervals rose to prominence, to the advantage of everyday geological and paleontological practice. Biochrons are chronologic units of relative age. They have been con- ceived, understood, and used as such for decades by most paleontologists, prominently including mammal paleontologists.

Although mammal paleontologists have a long tradition of placing vertebrate evolution in stratigraphic and biochronologic contexts, the term biochronology was rarely used prior to the 1970s when the application of radiometric dating became widespread and the distinction was made between radiochronology and biochronology as different aspects of geochronology (cf. Berggren $\&$ Van Couvering 1974). According to the original definition by Williams (1901), a biochron is "a time unit whose measure is the endurance of an organic character". Based on this definition, Berggren and Van Couvering (1974) suggested the application of the term biochron for units of 
geologic time that are based on paleontological data without reference to lithostratigraphy or rock units. Thus, in principle, the emphasis on mammal occurrences in time rather than in rocks distinguishes biochronology from other chronologic systems (Lindsay \& Tedford 1990). Biochronology is an important concept for geochronology, but its use has been compromised by a history of diverse meanings assumed by different researchers, and by the fact that it has never been discussed in any stratigraphic code because of that "loose and ambiguous" application. Furthermore, biochronology is important to vertebrate chronology because the primary temporal units developed and applied by vertebrate paleontologists for correlation in terrestrial deposits are all biochronologic entities. These timescales are built in terms of conventional mammal biostratigraphic zones or land mammal ages (LMAs), as defined by Lindsay (2003: 222) "relatively short interval[s] of geological time that can be recognized and distinguished from earlier and later such units (in a given region or province) by a characterizing assemblage of mammals".

Well before Williams' definition, early attempts to define (and more importantly to use) land mammal biochrons trace back to Pareto (1865) who collapsed under the name Villafranchian, a group of Late Pliocene fossil mammal assemblages coming from the neighborhood of Villafranca d'Asti (northern Italy). The geographically and temporally limited attempt of Pareto was later greatly expanded upon. Locally, Azzaroli (1983) and Azzaroli et al . (1988) established a full biochronologic scheme for Pliocene and Early Pleistocene Italian mammal faunas by formalizing the Villafranchian mammal age (Rook \& Martinez-Navarro 2010). On a larger scale, the crucial advance over early, locallydefined land mammalian biochrons à la Pareto was Mein's (1975) introduction of continentallevel biochrons for the Neogene of Europe, the so-called Mammal Neogene (MN) zones (which are often colloquially referred to as Mein zones). Since Mein's monumental work in the 1970s, MNs have been reworked, expanded, and better defined (Bernor et al. 1996, Rössner \& Heissig 1999, Agusti et al. 2001). In addition, the European Land Mammal Mega Zones (a later development inclusive of the MN scheme) now go back to the Paleocene. Even more fundamental is the geographical expansion of the European example to North America (the NALMA system, Woodburne 1977, 1987, Woodburne \& Swisher 1995), South America (Marshall et al. 1983, Flynn \& Swisher 1995), Asia (Tong et al. 1995), and even Australia (Woodburne et al. 1985, Megirian et al. 2010), although the land mammal-based timescale on each continental landmass has its own history of development, reflecting the uniqueness of the records and the extent to which faunal succession has been resolved. A related term of choronofauna is different from biochrons. Whereas the former looks at the taxonomic composition of the fauna (and its change) as a whole, the difference between successive biochrons is delineated by the appearance/disappearance of specific taxa. Whereas this methodological difference is clear, the concepts of chronofaunas and biochrons are used interchangeably and often confounded, since they serve the same goal.

From the huge amount of work that led to the establishment of these timescales comes the intrinsic promise to one day create a global correlational scheme of mammal-bearing outcrops. Beyond pure biochronology, such a superscheme would allow the study of the multifaceted, complex and partly independent evolution of mammalian clades, the history of their distribution, the fate of individual groups, the way they responded to environmental crises and to major tectonic events, and to the ongoing competition between ecologically similar lineages, or between predators and prey. These questions go far beyond the biochronologic schemes themselves, and the (practical) reason they were created to begin with. For instance, teasing apart the effects of abiotic and biotic factors on species temporal turnover is a classic of evolutionary biology, and one of the battlefields where gradualists and punctuationists meet (Van Valen 1973, Barnosky 2001, Raia et al. 2005, Benton 2009). Ironically, the better the biochronologic schemes become, the more Lyell's original, evolutionary vein is relevant. Biochrons can be, and in fact increasingly are, used to understand the evolution of mammal communities (and hence of biodiversity itself [Fritz et al. 2013, Diniz-Filho et 
al. 2013]), bridging the gaps between the many professions mammalian paleontologists happen to practice.

\section{How many professions are there?}

We are not aware of any raw data on this, nor have we set up an experiment, yet we are convinced that most vertebrate paleontologists perceive the existence of different disciplines within their own field. A dense fossil record and literally thousands of living relatives to draw upon is a commodity that a paleontologist working on either dinosaurs, birds, squamates, acanthodians or any other group besides mammals simply does not have access to. Most vertebrate paleontologists are in fact systematists, and others (a minority) are paleobiologists. The good news is that these two broad categories cut across the vertebrate classes. Yet, it takes mammals to be a biochronologist in vertebrate paleontology. Sadly though, although mammalian biochronologists are well aware of (and some in fact are) systematists as well, few of them are paleobiologists tout court. The reason for this is quite obvious: biochronology requires a good deal of purely sedimentological knowledge, and the latter comes with geology classes. In fact, whereas many paleontological systematists and paleobiologists have a zoological background (e.g. Alfred Romer and Elizabeth Vrba) most mammalian biochronologists have a degree in geology or are otherwise keen on sedimentology (a few notable exceptions are geology-trained paleobiologists with an inordinate fondness for narrative writing, consider Björn Kurtén for mammals, and also of George G. Simpson and Stephen J. Gould as broader based paleontologists). In this regard, it is not surprising that many mammalian biochronologists are, in a sense, more closely connected to other, non-vertebrate paleontologists, such as paleontological stratigraphers, than most fellow vertebrate paleontologists are. Although presented in a simplistic fashion and therefore limited in scope, we believe this complex situation in part explains why mammalian biochrons parted ways with Lyell's original evolutionary connection, and mammalian paleobiology, although vivid and productive over the years to the extent of locating paleontology within the Modern Evolutionary Synthesis via Simpson's magnus opere in the 1940s and 1950s (Simpson 1944, 1949, 1953) usually has little to do with biochrons. We believe the quest for this missing link can now be embraced, that this is timely, and that we have a lot to gain from bridging the gap.

\section{Evolution above the species level, and at the community level}

Richard Dawkin's selfish gene theory (Dawkins 1976) exacerbated the clash between the adaptationist, gene-centered view of evolution and the importance of selection at the level of species (and above; Gould 2002) with which paleobiologists generally feel more comfortable. After early collisions, it now seems accepted that species selection is real, and empirical observations bear out this conclusion (Jablonski 2008). Regardless of whether species selection has much to do with the dynamics of diversification, it is important to community evolution (where "community" for a mammalian paleontologist can be equated with the species in a biochron).

To an ecologist, the evolutionary effects of biological interactions (where the field of interaction is the community) are obvious. For instance, species body sizes may adapt to the presence of similarly-sized competitors, leading to a pattern of evenly spaced body sizes within a subset (guild) of the community, restricted to species competing for the same resources. This pattern, known as community wide character displacement, is an active research field in ecology (Dayan \& Simberloff 2005, Meiri et al. 2011). Adaptation in the presence of strong competition is not always possible, though, and the poorer competitor often goes locally extinct (Grinnell 1904, Clayton \& Bush 2006). Extinction via competitive exclusion is, in fact, one of the multiple forms of species-level selection (or species sorting, that is the term many use). Unfortunately, though, evolutionary time is usually longer than ecological time. That is, since the effects of species selection (e.g. on diversification dynamics) are evolutionary in principle, it takes the study of communities at an evolu- 
tionary scale to fully understand how biological interactions affect diversification dynamics. As David Jablonski clearly put it (Jablonski 2008): "The fields of paleontology, comparative phylogenetic analysis, macroecology, and conservation biology are rich in examples of species sorting, but relatively few instances have been well documented, so the extent and efficacy of the specific processes remain poorly known. A general formalization of these processes remains challenging, but approaches drawing on hierarchical covariance models appear promising. Analyses integrating paleontological and neontological data for a single set of clades would be especially powerful."

In our view, biochrons (defined as a distinctive assemblage of potentially interacting species with a demarcated temporal and geographical extent) provide the study of community evolution with a profitable reference unit. Surprisingly, though, as we have pointed out above, this possibility has been little explored in the past.

Jablonski claimed that macroecology (i.e. the study of major patterns in trait and geographical distribution of species within clades; Brown 1989, Gaston \& Blackburn 2000) rightfully stands within the discipline, providing examples for species selection. We attach special importance to macroecology in the present context for one specific reason (which is operationally and philosophically relevant to the use of paleontological data to understand species selection processes, and ultimately, diversity dynamics) that is: macroecology has the geographical dimension. We argue that this dimension has usually been given little attention by paleobiologists, and that this partial ignorance has impeded rethinking and reusing biochrons in an evolutionarilyoriented context. Why does geography matter? Because when a species disperses (on a paleontological time scale), either to track its preferred habitat in the wake of climate change, or to profit from an ecologically vacant space left by a vanished competitor, it will encounter other species, will interact with them, and both the movement itself and the outcome of these interactions will determine its fate, i.e., its survival, and ultimately the timing of its extinction. From a phylogenetic perspective, the fact that phylogenetically related species possess similar traits, share key innovations for the most part, and have ecologically similar requirements, means that the geographic dimension will affect the fate not just of single species, but of entire clades, their survival, and their likelihood of diversifying. Ultimately, the geographic dimension interacts with community level processes to determine the evolution of traits, and diversification parameters for entire clades. Whereas this has received little attention in the paleobiological field, community ecologists are well aware of these effects, which they started to study at least a decade ago (Webb et al. 2002, Kraft et al. 2007). Community phylogenetics provides fundamental insights into the phylogenetic diversity of communities and its evolution (Faith 1992, Cavender-Bares \& Wilczek 2003). Crucial to the field of paleobiology, community phylogenetics expands the classic question of species temporal turnover (which is a description of a pattern) towards the phylogenetic dimension, showing which clades thrived and where, and through which traits, which is a description of the process of turnover in addition to the pattern itself (Raia 2010).

\section{The PCOM experience}

We aspire here to explain why community evolution matters to paleobiology in the broadest sense. We contend that biochrons (once their geographic dimension is recognized) are the fundamental unit of reference: they are the community for a mammalian paleontologist. But which biochrons (or which definition thereof) are the most appropriate? To a paleobiologist, what matters is a coherent assemblage of species that conceivably interacted to an extent, over a defined time span (Tedford 1970, Lindsay 2003, Palombo \& Sardella 2007). This may be linked to stratigraphic intervals (Salvador 1994, Ivany \& Schopf 1996), yet it clearly calls for biochrons that are not defined by the appearance/disappearance of specific taxa, but on whole-(taxonomic) list comparisons of different time/geographic intervals. In the latter context, paleontological communities have been shown to possess some of the properties of extant communities, such as ecosystem resilience (the ability to resist intermediate levels of disturbance), which in the pale- 
ontological literature is known as coordinated stasis (Ivany \& Schopf 1996, Brett et al. 2009, but see Alroy 1996). To a mammalian paleobiologist, biochrons may serve this same purpose.

In theory, the geographical limits of a biochron are one of its components (Tedford 1970). On practical grounds, though, these geographic boundaries are vague, and biochrons are often given temporally non-overlapping distributions, which means that they rarely diverge geographically in contiguous areas (e.g. a continent) although they should in principle do so. This makes biochrons very like stratigraphic biozones (assemblage zones, cf. De Giuli et al. 1988) or chronofaunas, and thus less likely to be used in an evolutionary sense. This is possibly linked to the geological background of biochronology as a discipline. As we noted above, it is likely that most biochronologists are simply satisfied with temporally non-overlapping biochrons. Is there any way to break this fourth wall? To do this it takes some specific metric to identify taxonomically distinct assemblages, geographic references for the fossil sites under scrutiny, and, perhaps more importantly, numerical dating of the sites. The reason for the latter is not intuitive and requires comment. Without numerical dating, fossil sites are clustered on the basis of their taxonomic resemblance and nothing else. If taxonomic composition changes over a specific geographic extent (which is obvious as soon as one thinks of living communities), biochrons will include the distribution of species from one extreme to the other of their geographic distribution. This means that biochrons without numerical dating of the fossil sites can be strongly diachronous (Alroy 1998), which negates the geographic dimension of taxonomic turnover (akin to beta diversity in ecology). To remedy this problem absolute dating is necessary. Absolute age estimates are notoriously rare in paleontology. Fortunately, this limitation can now be overcome by at least two different statistical approaches: Alroy's ML AEO (Alroy 2000), and spectral ordering (Fortelius et al. 2006, Puolamäki et al. 2006).

We took all of the above into account to attempt a potential solution in producing the paleocommunity (PCOM) and Eurasian paleocommunity (EA PCOM) systems (Raia et al. 2005, 2006b, 2009). PCOM is a group of fossil sites which form a statistically distinctive group in terms of its taxonomic component. Once fossil sites are numerically dated via ordination (Alroy 2000, Fortelius et al. 2006, Puolamäki et al. 2006), PCOM (which equates to a biochron in our evolutionary-oriented definition) has a temporal limit (defined by the youngest and oldest site it includes) and a geographic distribution (defined by the geographical coordinates of the sites it includes). The good news with PCOMs is that they are statistically similar to living communities in terms of species body size frequency distribution and abundance distribution (Raia et al. 2006a, Carotenuto et al. 2010), and were proved to be very successful in terms of studying the evolution of mammalian communities from the Pliocene to the Recent (Meloro et al. 2007, 2008), suggesting that once biochrons are conceptualized in evolutionary terms they will help bridge the gap between paleontological and neontological theories and data in understanding the evolution of biodiversity in the broad sense. The bad news is that since PCOMs do have a temporal distribution, they are essentially different from living communities. This means that although the study of community evolution could be approached by using PCOMs, community evolution is already present within PCOMs. This is potentially problematic and must be kept in mind while PCOM, units of coordinate stasis or any other ecological-evolutionary concept of biochron is used.

\section{Communities and climate change}

The world is living a moment of dramatic change, if not the sixth mass extinction itself (Barnosky et al. 2011, 2012). While humans are at least partially to blame for this havoc, the current biodiversity crisis is mostly about climate change, and what happens to species in the wake of change. Mammalian paleontologists are the established experts on long-term effects of climatic change on species distribution and evolution. And they have provided a wealth of consistent information on the subject matter. Individual lineages and communities of mammals can now be used to understand the evolution of terrestrial biomes, and their fates (Fortelius et al. 2002, 
Fortelius \& Zhang 2006, Damuth \& Fortelius 2001, Eronen et al. 2009, Liu et al. 2009, Passey et al. 2009, Eronen et al. 2010a, 2010b).

Interest of mammalian paleontologists in the relationship between climate change and mammalian evolution is not new. What is new, and we feel most promising, is the richness of information and theories that mammalian paleobiologists have realized from joining their interests with conservation biologists, in the attempt to understand the causes biodiversity loss. As the world's biota are responding to the harmful effects of biotic homogenization (Olden 2008), habitat loss and degeneration (Novacek 2001), and human overexploitation of resources, having first-hand information on what effects these phenomena (or some of them) produced in the past is crucial to the proposal of possible remedies for the current biodiversity crisis. On the one hand, humans have been shown to be the fiercest over-killers of them all (Alroy 2001), and prey species were little equipped to deal with our technological advancements (Gittleman \& Gomper 2001). Further back in the past, the history of mammalian faunas can now be correlated with human dispersal and evolution itself, in order to gain understanding of human/large mammal interaction dynamics (Turner 1984, Arsuaga et al. 1993, FernándezJalvo et al. 1999, Eronen \& Rook 2004, Lordkipanidze et al. 2007, O’Regan 2008, RodrìguezGomez et al. 2013). Having this information on hand means understanding what the tempo and mode of species survival were in the past. It is clear to conservationists that acting to save threatened species in isolation is often bound to fail, because species are part of the community they live in and interact with (Nicholson \& Possingham 2006). Conservation biologists are relying more and more on the fossil record (e.g. McCallum 2007, Diniz-Filho et al. 2013), and we feel that mammalian paleontologists should be scientifically keen and morally obliged to work alongside conservation biologists in the attempt to ameliorate the current biodiversity crisis.

\section{Acknowledgements}

We are grateful to Jussi Eronen, Jukka Jernvall, Anu Kaakinen, Pirkko Ukkonen, Suvi Viranta for inviting us to contribute to this volume. Lars Werdelin and Raymond L Bernor kindly reviewed an earlier version of this manuscript, curing our excessive fondness for prose and tightening the arguments presented here. On top of all we thank Mikael Fortelius for years of continuing collaboration, inspiration, and amazingly hilarious moments spent together in the past.

\section{References}

Agusti, J., Cabrera, L., Garces, M., Krijgsman, W., Oms, O. \& Peres, J. M. 2001: A calibrated mammal scale for the Neogene of western Europe. State of the art. - EarthScience Reviews 52: 247-260.

Alroy, J. 1996: Constant extinction, constrained diversification, and uncoordinated stasis in North American mammals. - Palaeogeography, Palaeoclimatology, Palaeoecology 127: 285-311.

Alroy, J. 1998: Diachrony of mammalian appearance events: implications for biochronology. - Geology 26: 23-27.

Alroy, J. 2000: New methods for quantifying macroevolutionary patterns and processes. - Paleobiology 26: $707-733$

Alroy, J. 2001: A multi-species overkill simulation of the end-Pleistocene megafaunal mass extinction. - Science 292: 1893-1896.

Arsuaga, J. L., Martinez, L., Gracia, A., Carretero, J. M. \& Carbonell, E. 1993: Three new human skulls from the Sima de los Huesos Middle Pleistocene site in Sierra de Atapuerca, Spain. - Nature 362: 534-537.

Azzaroli, A. 1983: Quaternary mammals and the end-villafranchian dispersal event - a turning point in the history of Eurasia. - Palaeogeography, Palaeoclimatology, Palaeoecology 44: 117-139.

Azzaroli, A., De Giuli, C., Ficcarelli, G. \& Torre, D. 1988: Late Pliocene to early mid-Pleistocene mammals in Eurasia: faunal succession and dispersal events. - Palaeogeography, Palaeoclimatology, Palaeoecology 66: 77-100.

Barnosky, A. D. 2001: Distinguishing the effects of the Red Queen and Court Jester on Miocene mammal evolution in the northern Rocky Mountains. - Journal of Vertebrate Paleontology 21: 172-185.

Barnosky, A. D., Matzke, N., Tomiya, S., Wogan, G., Swartz, B., Quental, T., Marshall, C., McGuire, J. L., Lindsey, E. L., Maguire, K. C., Mersey, B. \& Ferrer, E. A. 2011: Has the Earth's sixth mass extinction already arrived? Nature 471: 51-57.

Barnosky, A. D., Hadly, E. A., Bascompte, J., Berlow, E. L., Brown, J. H., Fortelius, M., Getz, W. M., Harte, J., Hastings, A., Marquet, P. A., Martinez, N. D., Mooers, A., Roopnarine, P., Vermeij, G., Williams, J. W., Gillespie, R., Kitzes, J., Marshall, C., Matzke, N., Mindell, D. P., Revilla, E. \& Smith, A. B. 2012: Approaching a state shift in Earth's biosphere. - Nature 486: 52-58.

Benton, M. J. 2009: The Red Queen and the Court Jester: species diversity and the role of biotic and abiotic factors through time. - Science 323: 728-732.

Berggren, W. A. \& Van Couvering, J. A. 1974: The late Neo- 
gene: biostratigraphy, geochronology and paleoclimatology of the last 15 million years in marine and continental sequences. - Palaeogeography, Palaeoclimatology, Palaeoecology 16: 1-216.

Bernor, R. L., Fahlbusch, V., Mittmann, H.-W. \& Rietschel, S. (eds.) 1996: The evolution of western Eurasian Neogene mammal faunas. - Columbia University Press, New York.

Brett, C. E., Ivany, L. C., Bartholomew, A. J., DeSantis, M. K. \& Baird, G. C. 2009: Devonian ecological-evolutionary subunits in the Appalachian Basin: a revision and a test of persistence and discreteness. - Journal of the Geological Society of London, Special Publication 314: 7-34.

Brown, J. H. 1995: Macroecology. - University of Chicago Press.

Carotenuto, F., Barbera, C. \& Raia, P. 2010: Occupancy, range size and phylogeny in Eurasian Pliocene to recent large mammals. Paleobiology 36: 399-414.

Cavender-Bares, J. \& Wilczek, A. 2003: Integrating microand macroevolutionary processes in community ecology. - Ecology 84: 592-597.

Clayton, D. H. \& Bush, S. E. 2006: The role of body size in host specificity: Reciprocal transfer experiments with feather lice. - Evolution 60: 2158-2167.

Dayan, T. \& Simberloff, D. 2005: Ecological and community-wide character displacement: the next generation. - Ecology Letters 8: 875-894.

Damuth, J. \& Fortelius, M. 2001: Reconstructing mean annual precipitation, based on mammalian dental morphology and local species richness. - In: Agustí, J. \& Oms, O. (eds.), EEDEN Plenary Workshop on Late Miocene to Early Pliocene Environments and Ecosystems: 23-24. EEDEN Programme, European Science Foundation, Sabadell (Spain).

Dawkins, R. 1976: The selfish gene. - Oxford University Press, New York.

Diniz-Filho, J. A. F., Loyola, R. D., Raia, P., Mooers, A. O. \& Bini, L. M. 2013: Darwinian shortfalls in biodiversity conservation. - Trends in Ecology and Evolution 28: 689-695

De Giuli, C., Ficcarelli, G. \& Torre, D. 1988: Mammal sequences and biostratigraphy. - Memorie della Società Geologica Italiana 31: 131-133.

Eronen, J. \& Rook, L. 2004: The Mio-Pliocene European primate fossil record: dynamics and habitat tracking. Journal of Human Evolution 47: 323-341.

Eronen, J. T., Ataabadi, M., Micheels, A., Karme, A., Bernor, R. L. \& Fortelius, M. 2009: Distribution history and climatic controls of the Late Miocene Pikermian chronofauna. - PNAS 106: 11867-11871.

Eronen, J. T., Puolamäki, K., Liu, L., Lintulaakso, K., Damuth, J., Janis, C. \& Fortelius, M. 2010a: Precipitation and large herbivorous mammals, part I: estimates from present-day communities. - Evolutionary Ecology Research 12: 217-233.

Eronen, J. T., Puolamäki, K., Liu, L., Lintulaakso, K., Damuth, J., Janis, C. \& Fortelius, M. 2010b: Precipitation and large herbivorous mammals, part II: application to fossil data. - Evolutionary Ecology Research 12:
235-248.

Faith, D. P. 1992: Conservation evaluation and phylogenetic diversity. Biological Conservervation 61: 1-10.

Fernández-Jalvo, Y., Carlos Díez, J. \& Cáceres, I. 1999: Human cannibalism in the Early Pleistocene of Europe (Gran Dolina, Sierra de Atapuerca, Burgos, Spain). Journal of Human Evolution 37: 591-622.

Flynn, J. J. \& Swisher, C. C. 1995: Cenozoic South American land mammal ages: correlation to global geochronologies. - In: Berggren, W. A., Kent, D. V., Aubry, M.-P. \& Hardenbol, J. (eds.), Geochronology, time scales, and global stratigraphic correlation: 317-333. Society for Sedimentary Geology, Tulsa, OK.

Fortelius, M., Eronen, J. T., Jernvall, J., Liu, L., Pushkina, D., Rinne, J., Tesakov, A., Vislobokova, I. A., Zhang, Z. \& Zhou, L. 2002: Fossil mammals resolve regional patterns of Eurasian climate change during 20 million years. - Evolutionary Ecology Research 4: 1005-1016.

Fortelius, M., Gionis, A., Jernvall, J. \& Mannila, H. 2006: Spectral ordering and biochronology of European fossil mammals. - Paleobiology 32: 206-214.

Fortelius, M. \& Zhang, Z. 2006: An oasis in the desert? History of endemism and climate in the Late Neogene of North China. - Palaeontographica A 277: 131-141.

Fritz, S. A., Schnitzler, J., Eronen, J. T., Hof, C., BöhningGaese, K. \& Graham, C. H. 2013: Diversity in time and space: wanted dead and alive. - Trends in Ecology and Evolution 1701: 8.

Gaston, K. \& Blackburn, T. 2000: Pattern and process in macroecology. - Blackwell Science, London (UK).

Gittleman, J. L. \& Gomper, M. E. 2001: The risk of extinction - what you don't know will hurt you. - Science 291: 997-999.

Gould, S. J. 2002: The structure of evolutionary theory. The Belknap Press of Harvard University Press.

Grinnell, J. 1904: The origin and distribution of the chestnutbacked chickadee. - The Auk 21: 364-382.

Ivany, L. C. \& Schopf, K. M. 1996: New perspectives on faunal stability in the fossil record. - Palaeogeography, Palaeoclimatology, Palaeoecology 127: 1-4.

Jablonski, D. 2008: Species selection: theory and data. Annual Review in Ecology, Evolution and Systematics 39: 501-524.

Kraft, N. J. B., Cornwell, W. K., Webb, C. O. \& Ackerly, D. D. 2007: Trait evolution, community assembly, and the phylogenetic structure of ecological communities. American Naturalist 170: 271-283.

Lindsay E. H. 1990. The setting. - NATO ASI Series A, Life Sciences 180: 1-14.

Lindsay, E. 2003: Chronostratigraphy, biochronology, datum events, land mammal ages, stage of evolution, and appearance event ordination. - Bulletin of the American Museum of Natural History 279: 212-230.

Lindsay, H. \& Tedford, R. H. 1990: Development and application of Land Mammal Ages in North America and Europe, and comparison. - NATO ASI Series, A Life Sciences 180: 601-624.

Liu, L., Eronen, J. T. \& Fortelius, M. 2009: Significant midlatitude aridity in the middle Miocene of East Asia. - Palaeogeography, Palaeoclimatology, Palaeoecology 
279: 201-206

Lordkipanidze, D., Jashashvili, T., Vekua, A., Ponce de Leòn, M. S., Zollikofer, C. P. E., Rightmire, G. P., Pontzer, H., Ferring, R., Oms, O., Tappen, M., Bukhsianidze, M., Agustí, J., Kahlke, R., Kiladze, G., Martìnez-Navarro, B., Mouskhelishvili, A., Nioradze, M. \& Rook, L. 2007: Postcranial evidence from early Homo from Dmanisi, Georgia. - Nature 449: 305-310.

Marshall, L. G., Hofstetter, R. \& Pascual, R. 1983: Paleovertebrata. - Mém. Extraord. 1983: 1-93.

McCallum, M. L. 2007: Amphibian decline or extinction? Current declines dwarf background extinction rate. Journal of Herpetology 41: 483-491.

Megirian, D., Prideaux, G. J., Murray, P. F. \& Smit, N. 2010: An Australian land mammal age biochronological scheme. - Paleobiology 36: 658-671.

Mein, P. 1975: Resultats du groupe de travail des vertébrés. Working Groups. - In: Senes, J. (ed.), Report on activity of the R.C.M.N.S.: 78-81. Regional Committee on Mediterranean Neogene Stratigraphy, Bratislava.

Meiri, S., Simberloff, D. \& Dayan, T. 2011: Communitywide character displacement in the presence of clines: a test of Holarctic weasel guilds. - Journal of Animal Ecology 80: 824-834.

Meloro, C., Raia, P. \& Barbera, C. 2007: Effect of predation on prey abundance and survival in Plio-Pleistocene mammalian communities. - Evolutionary Ecology Research 9: 505-525.

Meloro, C., Raia, P., Carotenuto, F. \& Barbera, C. 2008: Diversity and turnover of Plio-Pleistocene large mammal fauna from the Italian Peninsula. - Palaeogeography Palaeoclimatology Palaeoecology 268: 58-64.

Nicholson, E. \& Possingham, H. P. 2006: Objectives for multiple species conservation planning. - Conservation Biology 20: 871-881.

Novacek, M. J. 2001: The biodiversity crisis: losing what counts. - The New Press, New York.

Olden, J. D. 2008: Biotic homogenization. In: Encyclopedia of Life Sciences (ELS). - John Wiley \& Sons, Chichester.

O'Regan, H. J. 2008: The Iberian peninsula - corridor or cul-de-sac? Mammalian fauna chnage and possible routes of dispersal in the last 2 million years. - Quaternary Science Reviews 27: 2136-2144.

Palombo, M. R. \& Sardella, R. 2007: Biochronology versus biostratigraphy: a true dilemma or a false trouble? The example of the Plio-Pleistocene large mammalian faunas from the Italian peninsula. - Quaternary International 160: 30-42.

Pareto, L. 1865: Note sur les subdivisions que l'on pourrait établir dans les terrains tertiaires de l'Apennin septentrional. - Bulletin de la Société Géologique de France 22: 210-277.

Passey, B. H., Ayliffe, L. K., Kaakinen, A., Zhang, Z., Eronen, J. T., Zhu, Y., Zhou, L., Cerling, T. E. \& Fortelius, M. 2008: Strengthened East Asian summer monsoons during a period of high-latitude warmth? Isotopic evidence from Mio-Pliocene fossil mammals and soil carbonates from northern China. - Earth and Planetary Science Letters 277: 443-452.
Puolamäki, K., Fortelius, M. \& Mannila, H. 2006: Seriation in paleontological data using Markov chain Monte Carlo methods. - PLoS Computational Biology, 2(2), e6, doi: 10.1371/journal.pcbi.0020006.

Raia, P., Piras, P. \& Kotsakis, T. 2005: Turnover pulse or red queen? Evidence from the large mammal communities during the Plio-Pleistocene of Italy. - Palaeogeography Palaeoclimatology Palaeoecology 221: 293-312.

Raia, P., Meloro, C., Loy, A. \& Barbera, C. 2006a: Species occupancy and its course in the past: macroecological patterns in extinct communities. Evolutionary Ecology Research 8: 181-194.

Raia, P., Piras, P. \& Kotsakis, T. 2006b: Detection of PlioQuaternary large mammal communities of Italy: integration to biochronology. - Quaternary Science Reviews 25: 846-854.

Raia, P., Meloro, C. \& Barbera, C. 2007: Inconstancy in predator/prey ratios in Quaternary large mammal communities of Italy, with an appraisal of mechanisms. Quaternary Research 67: 255-263.

Raia, P., Carotenuto, F., Meloro, C., Piras, P., Barbera, C. \& Kotsakis, T. 2009: More than three million years of community evolution. The temporal and geographical resolution of the Plio-Pleistocene Western Eurasia mammal faunas. - Palaeogeography Palaeoclimatology Palaeoecology 276: 15-23.

Raia, P. 2010: Phylogenetic community assembly over time in Eurasian Plio-Pleistocene mammals. - Palaios 25: 327-338.

Rodríguez-Gómez, G., Rodríguez, J., Martín-González, J. A., Goikoetxea, I. \& Mateos, A. 2013: Modeling trophic resource availability for the first human settlers of Europe: The case of Atapuerca TD6. - Journal of Human Evolution 64: 645-657.

Rook, L. \& Martínez-Navarro, B. 2010: Villafranchian: The long story of a Plio-Pleistocene European large mammal biochronologic unit. - Quaternary International 219: 134-144.

Rössner, G. E. \& Heissig, K. (eds.) 1999. Land mammals of Europe. - Verlag Dr. Friedrich Pfeil, München.

Rudwick, M. J. S. 1978. Charles Lyell's dream of a statistical paleontology. - Paleontology 21: 225-244.

Salvador, A. 1994: International stratigraphic guide. A guide to stratigraphic classification, terminology, and procedure. - The Geological Society of America, Boulder.

Simpson, G. G. 1940: The meaning of evolution. - Yale University Press, New Haven.

Simpson, G. G. 1944: Tempo and mode in evolution. Columbia University Press, New York.

Simpson, G. G. 1953: The major features of evolution. Columbia University Press, New York.

Tedford, R. H. 1970: Principles and practices of mammalian geochronology in North America. - In: Proceedings of the North American Paleontological Convention, part F: 666-703.

Tong, Y. S., Zheng, S. H. \& Qiu, Z. D. 1995: Cenozoic mammal ages of China. - Vertebrata PalAsiatica 33: 290-314. [In Chinese with English summary].

Turner, A. 1984: Hominids and fellow travellers: human migration into high latitudes as part of a large mammal 
community. - In: Foley, R. (ed.), Hominid evolution and community ecology: 193-217. Academic Press, London.

Van Valen, L. 1973: A new evolutionary law. - Evolutionary Theory 1: 1-30.

Webb, C. O., Ackerly, D. D., McPeek, M. A. \& Donoghue, M. J. 2002: Phylogenies and community ecology. Annual Review in Ecology and Systematics 33: 475-505.

Williams, H. S. 1901: The discrimination of time values in geology. - Journal of Geology 9: 570-585.

Woodburne, M. O. 1977: Definition and characterization in mammalian chronostratigraphy. - Journal of Paleontology 51: 220-234.

Woodburne, M. O. (ed.) 1987: Cenozoic mammals of North
America: geochronology and biostratigraphy. - University of California Press.

Woodburne, M. O. \& Swisher, C. C. III 1995. Land mammal high-resolution geochronology, intercontinental overland dispersals, sea level, climate, and vicariance. - In: Berggren, W. A., Kent, D. V., Aubry, M.-P. \& Hardenbol, J. (eds.), Geochronology, time scales and global stratigraphic correlation: 336-364. Society of Sedimentary Geology Special Publication No. 54, Tulsa, OK.

Woodburne, M. O., Tedford, R. H., Archer, M., Turnbull, W. D., Plane, M. D. \& Lundelius, E. L. 1985: Biochronology of the continental mammal record of Australia and New Guinea. - Special Publication of the South Australian Department of Mines and Energy 5: 347-363. 